\title{
Research on the Impact of VRS on BSNL, Especially the Kerala Telecom Circle
}

\author{
Dr. Sreekumar D Menon \\ DLitt, PhD, Ed. D, MPhil, MSc, MBA, MS, MHRM, MA \\ PGDLL \& AL, PGDMM, PGDPC, PGDPM\&IR, PGDDM \\ MIMA, ACT (UK), FDP (IIT), FDP (IIM) \\ Former Assistant General Manager - RTTC - BSNL, Trivandrum, Kerala, India \\ Guest Faculty -CDST (KVASU), Trivandrm, Kerala, India \\ Adjunct Faculty -LUC - MRC, Kuttikanam, Kerala, India \\ menonsayoojya@gmail.com
}

\begin{abstract}
BSNL (old DOT) is the pioneer telecom service provider in India. A few years back it was the seventh - largest telecom company in the world. It is a PSU with a huge infrastructure. Before implementing VRS it had more experienced employees, a lot of public utility services through customer service centers. It started to show the loss from 2009 - 10 financial year onwards. Its continuous loss and shortage of income - generating made as an obstacle for future development. All over India, a total of 78569 employees took VRS, Out of this 4596 were Kerala telecom circles contributed. Before the implementation of VRS salary distribution to staff was highly irregular, some time salary was received once in two months. To get salary on - time $71 \%$ of the employees opted VRS, It was informed before VRS that 60 - $70 \%$ of its income spend on the salary of the staff. With the hope that the remaining staff will get a salary in due time, the majority opted for VRS, but the financial position not improved as all the bills are pending, salary not giving on time, no technological advancement is introduced in the PSU.
\end{abstract}

Keywords: employees, salary, technology, retirement, customers

\section{Introduction}

Telecommunications play an important role in the world economy. BSNL (old DOT) is the first telecom service provider in India and other major telecom operators are Idea, Airtel, Vodafone, Reliance JIO, and MTNL. MTNL\&BSNL are two PSUs. Mobile phones have a significant impact on telecom networks. As per the new telecom policy (NTP) of the Government of India in 1990, the Indian telecom industry has undergone major structural change as part of liberalization. Both public and private telecom sector players actively entered into the rapidly growing telecommunication requirement in India.

BSNL (Bharath Sanchar Nigam Limited) was incorporated on 15 th September 2000. It took over in providing all the business of telecom services and networking management from the erstwhile Department of Telecom Services (DTS) of Government of India with effective from 1st October 2000. It is one of the largest telecom and allied service providing PSU in India. It has installed quality telecom networks in the hook and corner of our country for winning the customer's confidence as part of their service

After the formation of BSNL first few years it was a profit making company. Later turn to huge loss. The details since its formation as below.

\begin{tabular}{|c|c|}
\hline Financial Year & Profit/Loss in crores \\
\hline $2000-01$ (from first October) & 747 (profit) \\
\hline $2001-02$ & 6312 \\
\hline $2002-03$ & 1444 \\
\hline $2003-04$ & 5976 \\
\hline $2004-05$ & 10183 \\
\hline $2005-06$ & 8939 \\
\hline $2006-07$ & 7805 \\
\hline
\end{tabular}

\begin{tabular}{|c|c|}
\hline $2007-08$ & 3009 \\
\hline $2008-09$ & 575 \\
\hline $2009-10$ & -1823 (Loss) \\
\hline $2010-11$ & -6384 \\
\hline $2011-12$ & -8851 \\
\hline $2012-13$ & -7884 \\
\hline $2013-14$ & -7085 \\
\hline $2014-15$ & -8234 \\
\hline $2015-16$ & -4859 \\
\hline $2016-17$ & -4793 \\
\hline $2017-18$ & -7992 \\
\hline $2018-19$ & -14202 \\
\hline $2019-20$ & -15500 \\
\hline $2020-21$ & -7441 \\
\hline
\end{tabular}

Source: BSNL finance statement

In India, BSNL is divided into 27 telecom circles for operational convenience. Kerala telecom circle is one among them and it is again divided into 11 secondary switching areas (SSA) for operational and administrative convenience. Each SSA is again divided into 8 to 10 divisions and divisions into subdivisions. A few years back as part of the intensification of business all these SSAs were renamed as BAs (Business areas). After the implementation of VRS, staff strength was reduced, so two - three divisions merged and formed cluster areas. The operational areas of each BAs include both rural and urban areas. Employees are working in both areas. Two categories of employees working in BSNL, are executives and non - executives.

When DOT changed to BSNL on 1st October 2000, a sum of rupees forty thousand crores was with BSNL as surplus. This surplus was taken back by the Government by telling the reason like the cost of the spectrum (spectrum charge), license fees, etc. At the time of formation of BSNL, the Government of India had offered several promises like POI (point of interconnection) charge from other operators for 
using BSNL networks, USO (Universal Subscriber Obligation) funds for providing service in rural /remote areas. Unfortunately, Government violated these promises.

After the formation of BSNL, the profit of the company found decreasing day by day. So BSNL Corporate office has taken consultation from world - renowned consultation company BCG (Boston Consultation Group). The report they submitted is generally called Aspiration Driven Transformation (ADT) or called "Project Shikkar". Several projects were launched to improve the revenue of BSNL in several fields. For capturing and improving the BSNL, it adopted some strategies, like technology strategy, restructuring of organization based on business type and pricing strategy, etc to compete with other operators. Even though several hard works was done in the organization, the loss of the company increased year after year.

In 2017 IIM Ahmadabad submitted a report for the improvement of BSNL and turn it into a profitable organization. All the reports have shown that about $70-80$ percentage of BSNL revenue is spent on the salary of the employees. If BSNL reduces the employees' strength to 60 70 thousand, a huge amount spends on salary can be eliminated. When this proposal came first, all trade unions /organizations opposed it but were later bound to accept VRS as a huge delay is experienced in getting the salary. At present for paying the salary of BSNL employees only 300 core rupees are required. Revenue from the landline, broadband, and mobile sectors has come to the bottom. Only revenue is from FTTH only, that services have still complaint and the majority of these services (FTTH) are giving on revenue sharing basis with local cable operators

Though staffs are willing to work, no infrastructure is available to compete with the private operators. We required $5 \mathrm{G}$, not 4G. Government is not interested to improve the development of BSNL. At Present AMC is given to franchisees, not to experienced people especially landline and cable maintenance. The government's attitude shows that they are plans is to reduce landline and broadband.

Sampitroda's report was rejected by the Manmohan Sigh ministry in 2010, though it was for the improvement of BSNL. Again later part of 2017, the IIM Ahmadabad report came for the betterment of BSNL. They also suggested VRS implementation in BSNL for making it a profitable organization.

If you think about why BSNL going to lose, the answer is some of its positiveness. They are: 1) It is the only telecom operator which works during the disaster in any part of the country and also taking part in disaster relief and rescue, (2) During Amarnath Yathra (pilgrim) it is the only mobile operator having range throughout the journey, (3) BSNL is the only operator providing services in remote village areas across the country, (4) Never closing down any services like other operators if a loss occurs and (5) Offering cheapest tariff plans for mobile and broadband services with various pocket - friendly plans.

The young employees in BSNL came with better life and expectations. For all the employees BSNL is their bread and butter. After the VRS experts working in the copper lead is less. BSNL is the only telecom company in India with underground copper cable in the hook and nook of the corners of our country. At present this cable was managing by using outsourcing that is by temporary working employees if they get a good chance they will quit the job. Through copper, cable communications have no radiation. In the present condition, there is no chance to re - instate again the copper cable, which is radiation - free communications.

BSNL is still at the $3 \mathrm{G}$ level only. All the types of mobile equipment were imported from countries like Japan, China, France, etc. whether it is $3 \mathrm{G}, 4 \mathrm{G}$, or $5 \mathrm{G}$ optical fiber is the same for transmission. As per the Government policy (make in India/ Atma nirbharath) equipment should be manufactured in India for $4 \mathrm{G}$ and $5 \mathrm{G}$ for BSNL. Now some $2 \mathrm{G}$ spectrum using for $4 \mathrm{G}$, it is like bullock cart going through national highways with Audi/Benz engine. All mobile providers were providing service with harmful radiation to the human being. We have to maintain the copper cable network for radiation - free communication. All younger employees have full frustration and they do not have any expectations. For them make in India have not much scope due to the pandemic COVID time.

Though salary is not getting properly, have a belief that BSNL turns to profitable by $2024-25$. Till that time chances are there to get salary in delay. The Tax deducted from the VRS left employees and working employees not paid to the income tax department on time. This may be a reason for issuing form 16 for filing income tax. It is paid in July last and forms 16 issued in august last only.

Out of 163000 employees, 78569 employees took VRS. Non - executives opted more than the executives.13505 executives opted for VRS and 65064 numbers of non executives. In Kerala out of 9381 total employees, 4587 opted for VRS. An amount of 3294.77 crores allotted by the finance ministry for the implementation of VRS, In Kerala the ex - gratia given is Rs 7914029586 (seven hundred ninety - one crore, forty lakhs twenty - nine thousand and five hundred eighty - six rupees). Out of this 4587 employees, 680 were women balance 3907 were male. Out of the VRS opted employees 1004 were executives and 3583 were non - executives. If take individual ex - gratia received employees, highest got was one executive from Trivandrum (rupees seventy - seven lakhs fifteen thousand and one hundred seventy - one and least exgratia got is one telecom technician from Palghat BA with rupees eighty - six thousand four hundred thirteen.

Though salary is not getting properly, have a belief that BSNL turns to profitable by $2024-25$. Till that time chances are there to get salary in delay. The Tax deducted from the VRS left employees and working employees not paid to income tax department on time. This may be a reason in issuing form 16 for filing income tax. It is paid in August last week and form 16 is issued.

In land line more than $50 \%$ of the share was of BSNL. After the VRS most of the activities which is outsourced are:

a) Provisioning, O\&M of fixed lines, passive infrastructure b) Operation\& Maintenance of small exchanges 
c) Outdoor network rehabilitation work

d) Local loop maintenance

e) Underground cable jointing and maintenance

f) EPABX installation and $O \& M$

g) $\mathrm{BB}$ provisioning and maintenance

h) Passive infrastructure O\&M (power plant, battery, ac units)

Since the maintenance is very poor, the majority of the customers disconnected their landline and in mobile, port out to other operators. The government is going ahead for privatization, as part of that sharing of BSNL towers and other infrastructures started.

Kerala telecom circle was the only circle in BSNL having made profit except for last few years, balance all years it had profit, though altogether in BSNL is a loss.

\section{Objectives of the study}

The main objective of the study is to find the reason why the present plight of BSNL reached.

Other objectives are, the impact of VRS on BSNL, How can we improve the BSNL.

\section{Research Methodology}

Both primary and secondary data were taken into consideration for the study. Secondary data was collected from sources like BSNL financial statements, local newspaper details available in Google search, etc. Primary data are collected by taking responses from the following classes of people. (a) VRS 2019 opted staffs (b) working employees in BSNL, (c) Eligible for taking VRS, but not taken officials (d) willing to take VRS, but was not eligible, and (e) BSNL customers both wireline and wireless. Each questionnaire is different for each type with some of the questions are common.

\section{Findings}

1) Due to shortage of revenue, all the staffs were not received their salaries on time. This irregular payment of monthly salary led the employees to take VRS with the hope that the salary burden may reduce for balance non opted employees, but it is continuing.

2) All the participants want to improve the services of PSU (BSNL), especially in the mobile sector as it is the only one service existing when a disaster comes any were in the country.

3) The government's hidden agenda is to privatize the company (BSNL), because of this reason, they denying $4 \mathrm{G} \& 5 \mathrm{G}$ to BSNL.

4) Even though monetization started to generate funds, it is not coming for the improvement of services in BSNL.

5) Based on the performance output, salary and allowances are to be given.

6) Medical expenditure (for both retired and serving employees) to be met with the tie - up with some government insurance companies.
7) The present AMC (annual maintenance contract) is an utter failure especially landline services. Because of this 75 to $85 \%$ of landlines were closed by the public (customers.

8) Present staffs workload increased, but they have fewer tensions as almost all works are executing through AMCs

9) Job satisfaction in BSNL employees after VRS is less.

10) Due to delay in salary and all other payments leads to a stressful situation to staffs.

11) VRS taken staffs are happier and leading a peaceful life though only $40-45 \%$ of the salary (at the time of retirement) getting as pension.

12) Because of this pandemic COVID disease, chances to get employed in other firms are very less, this is making a lot of disappointment in younger employees of the organization.

13) Everybody who participated in the survey has the opinion that Government is supporting the corporate Reliance Jio to perish BSNL.

14) All of them have the opinion that after VRS union influence is weakened, which was a major burden to administration before VRS.

15) All the customers have the opinion that improvement of infrastructure and increase in staff responsibility can improve BSNL in the future.

16) All the participants have the opinion that without the direct involvement of the Government, improvement in BSNL is not possible as at present Govt is supporting reliance Gio to demolish the public sector telecom company BSNL. If the Government is willing to keep it as a PSU alive in disaster (all others will die if any disaster comes to the nation), this will go forward. All Government connections to be in PSU, then the chance of improvement of BSNL is possible.

17) In the present situation survival of BSNL is very difficult unless Government provide $4 \mathrm{G} \& 5 \mathrm{G}$ to $\mathrm{BSNL}$

18) The majority of the employees present in the organization after VRS are quite young and high qualifications and have the readiness to work for their survival, but the Government of India not taking initiative to keep BSNL as a proud PSU

\section{References}

[1] BSNL financial statements

[2] Various papers /articles available in Google search

[3] Articles published by self about BSNL's plight, issues, marketing etc in various international journals from 2014 to 2020 